\title{
Metabolic transformation of selenium (IV) by bacteria of the genus Azospirillum
}

Tugarova A.V., Mamchenkova P.V., Kamnev A.A.

Institute of Biochemistry and Physiology of Plants and Microorganisms, Russian Academy of Sciences, Saratov, Russia

E-mail: tugarova_anna@mail.ru

Key message. Possible mechanisms of selenite reduction by bacteria of the genus Azospirillum are studied. A method is proposed for producing extracellular Se nanoparticles homogeneous by size which have been characterised by various methods.

Keywords: selenium, selenium oxoanions, nanoparticles, Azospirillum

Bacteria are involved in the transformation of selenium compounds in different oxidation states, reducing selenium oxyanions, which are toxic owing to their solubility, to less toxic insoluble $\mathrm{Se}^{0}$ and selenides, often with the formation of nanoparticles. This phenomenon is of interest to various fields of biotechnology. In this work, we present the results of studies on the reduction of selenite ions $\left(\mathrm{SeO}_{3}{ }^{2-}\right.$, selenium in the oxidation state +4$)$ by bacteria of the genus Azospirillum. Eight species of Azospirillum were studied: A. brasilense, A. lipoferum, A. halopraeferens, A. thiophilum, A. zeae, A. formosense, A. palatum and $A$. picis. All of them were able to reduce selenite and form selenium nanoparticles (Se-NPs). Using the species $A$. brasilense, we studied the role of different mechanisms potentially involved in this process: the denitrification system, glutathione redox system, and $\mathrm{H}^{+}$-dependent transport. A scheme has been developed for obtaining extracellular Se-NPs homogeneous by size, including growth, purification and concentration of bacterial cells followed by incubation with sodium selenite [1]. Se-NPs synthesised by the species A. brasilense and A. thiophilum were studied using various methods: dynamic light scattering, TEM, vibrational spectroscopy (Fourier transform infrared and Raman spectroscopies), protein electrophoresis, etc. The Se-NPs had zeta potentials of -18.5 to $-23.7 \mathrm{mV}$, contained proteins, polysaccharides and lipids and consisted of $\mathrm{Se} 0$ in its amorphous modification [2,3]. Basing on the results obtained, we suggest that selenite reduction by azospirilla can include the following stages: (1) transport of $\mathrm{SeO}_{3}{ }^{2-}$ inside the cell; (2) intracellular reduction of selenite ions involving the denitrification system; (3) transport of the Se-NPs nuclei out of the bacterial cell involving proton motive forcedependent transport; (4) extracellular assembly of Se-NPs in the vicinity of the cell surface involving biological molecules. This study was supported by The Russian Foundation for Basic Research (Grant 16-08-01302-a).

\section{Метаболическая трансформация селена (IV) бактериями рода Azospirillum}

Тугарова А.В., Мамченкова П.В., Камнев А.А.

Институт биохимии и физиологии растений и микроорганизмов Российской академии наук, Саратов, Россия

Аннотация. Изучены возможные механизмы восстановления селенит-ионов бактериями рода Аzоsріrilluт. Подобрана схема получения экстраклеточных гомогенных по размеру наночастиц Sе, которые охарактеризованы различными методами.

Ключевые слова: селен, оксоанионы селена, наночастиць, Azospirillum

Бактерии участвуют в трансформации соединений селена в различных степенях окисления, восстанавливая токсичные, в силу своей растворимости, оксоанионы селена до менее токсичных нерастворимых элементарного селена и селенидов, часто - с формированием наночастиц. Этот феномен представляет интерес для различных областей биотехнологии. В данной работе представлены результаты исследования восстановления бактериями рода Azospirillum селенит-ионов $\left(\mathrm{SeO}_{3}{ }^{2-}\right.$, селен в степени окисления +4$)$. Было исследовано 8 видов азоспирилл: $A$. brasilense, A. lipoferum, A. halopraeferens, A. thiophilum, A. zeae, A. formosense, A. palatum и A. picis. Все они были способны восстанавливать селенит и образовывать наночастицы селена (Se-HЧ). На примере вида

A. brasilense изучено участие различных механизмов, потенциально вовлеченных в этот процесс: система денитрификации, редокс-система глутатиона и $\mathrm{H}^{+}$-зависимый транспорт. Подобрана схема для получения экстраклеточных гомогенных по размеру Se-HЧ, включающая выращивание, очистку и концентрирование бактериальных клеток с последующей инкубацией с селенитом натрия [1]. Синтезированные видами A. brasilense и A. thiophilum Se-НЧ исследованы с использованием различных методов: динамического рассеяния света, ПЭМ, колебательной спектроскопии (ИК-фурье-спектроскопии и спектроскопии комбинационного рассеяния), белкового электрофореза и др. Sе-НЧ имели дзета-потенциал от $-18,5$ до $-23,7$ мВ, содержали в своем составе белки, полисахариды и липиды и содержали элементарный селен в аморфной модификации [2,3]. На основе полученных результатов мы предполагаем, что восстановление селенит-ионов азоспириллами может включать следующие стадии: (1) транспорт $\mathrm{SeO}_{3}{ }^{2-}$ внутрь клеток; (2) внутриклеточное восстановление с включением селенит-ионов в систему денитрификации; (3) вынос зародышей Se-HЧ из бактериальных клеток посредством протон-зависимого транспорта; (4) внеклеточная сборка Se-НЧ вблизи поверхности клеток с участием биологических макромолекул.

Работа поддержана грантом РФФИ 16-08-01302-а.

1. Tugarova A.V. et al. New Biotechnol. 58 (2020) 17-24.

2. Kamnev A.A. et al. J. Mol. Struct. 1140 (2017) 106-112.

3. Tugarova A.V. et al. Spectrochim. Acta Part A: Mol. Biomol. Spectrosc. 192 (2018) 458-463. 